\title{
Mini-livestock production as a strategy for food security among households in Iwo, Nigeria
}

\author{
Odukoya S. O. ${ }^{1}$, Popoola M. A. ${ }^{1 \star}$, Adebisi G. L. ${ }^{1}$ and Tiamiyu A. K. ${ }^{2}$ \\ ${ }^{1}$ Federal College of Animal Health and Production Technology, Moor Plantation, Ibadan, Nigeria. \\ ${ }^{2}$ Institute of Agricultural Research and Training, Moor Plantation, Ibadan, Nigeria. \\ *Corresponding author. Email: herbyolar@gmail.com
}

Copyright (C) 2017 Odukoya et al. This article remains permanently open access under the terms of the Creative Commons Attribution License 4.0, which permits unrestricted use, distribution, and reproduction in any medium, provided the original work is properly cited.

Received 20th August, 2017; Accepted 21st September, 2017

\begin{abstract}
The study was conducted to assess mini-livestock production as strategy for food security among households in Iwo, Nigeria. Multi-stage sampling procedure was used to select 150 respondents. A structured interview schedule was used to elicit information from the respondents. Household food security was estimated using food security index to establish the food security status of various households. Thus, households were classified into food secured and food insecured. Data were subjected to both descriptive statistics and regression analysis. Most of the respondents were male (72.8\%), they were within the age bracket of 20-24 years, had secondary education (55\%), with household size between 2 to 5 members (45.7\%). The study further revealed that $52.3 \%$ of the respondents were Christian, were farmers $(35.1 \%)$ have 5 to 8 years of experience in mini livestock production. They earned more than $\mathrm{N} 5,000$ as income. Also most of the respondents raised mini-livestock purposely for income generation and sourced their flocks from wild $(39.1 \%)$. Most of the respondents were raising snail $(25.2 \%)$. Majority of the households in the study area were food secured. There is significant and strong correlation between raising of more than one species of minilivestock and food security of the households. Primary occupation and income realized from sales of mini livestock production were found to be significant determinants of food security among households.
\end{abstract}

Keywords: Flocks, food, production, secured, snail, status.

\section{INTRODUCTION}

Food security indicates the availability and access to food (Okunmadewa et al., 1990). According to Omonona and Agoi (2007), the committee on world food security defined it as physical and economic access to adequate food by all household members. Food insecurity is increasing in the world where 925 million people are undernourished; about 900 million people are living in developing countries (FAO, 2010). More than $70 \%$ of these people live in rural areas and depend, directly or indirectly on agriculture for their living. Usually, there are limited number of markets and less diversity and availability of food items in rural areas that affect food security (Morris et al., 1992). Food security at household level is a subset of the national level and it requires that all individuals and households have access to sufficient food either by producing it themselves or generating sufficient income to demand for it. In Nigeria, population of food insecured households was $18 \%$ in 1986
(Babatunde et al., 2007) but had increased to $40 \%$ in 2005 and is projected to be higher in the subsequent years (Sanusi et al., 2006).

Sustainable livestock production plays an important role in alleviating the condition of food insecurity among households. Minilivestock is a sustainable form of animal production that has significant potential for alleviating malnutrition and food insecurity (Assan, 2014). Minilivestock encompasses small indigenous vertebrates and invertebrates that can be produced on a sustainable basis for food, animal feed and as a source of income. These include snails, bush-rodents, grass cutter, rabbits, guinea pig, honey bee, worms, insects and many other small species. Mini-livestock is very much associated with increased food security as it lends itself to small scale family production (Assan, 2014). It contributes to food security and meeting up the recommended dietary animal protein (Hardouin et al., 2003). The small size of 
mini-livestock animals means a small amount of input per unit, which in turn means more flexible production. Backyard food production such as mini-livestock can be a major contributor to a more balanced diet for both rural and urban people (Ogunniyi et al., 2015).

Mini-livestock such as snail, rabbits, grass-cutters and quail are animal protein intake which are quite low in developing countries than in developed countries and the level of meat and animal protein consumed by Nigerian is estimated at $6 \mathrm{~g}$ per caput per-day which is about $29 \mathrm{~g}$ less than the minimum of $35 \mathrm{~g}$ daily requirement recommended by the food and agriculture organization (FAO, 2004). Unfortunately, the conventional and regular sources of animal protein supply in the country like beef, pork, goat meat and poultry are getting out of reach of the common populace due to the economic down-turn. There is therefore the need to look inward and integrate into farming system some non-conventional meat sources.

Therefore, as part of measures to improve the level of food insecurity and reduce undernourishment among the populace, there is an urgent need to encourage minilivestock production. Thus this study sought to assess mini-livestock production as a strategy for food security among households in Iwo, Nigeria.

\section{MATERIALS AND METHODS}

\section{Location of the study}

The study was conducted in Iwo, South western Nigeria. Iwo has four major Agricultural zones which are OlaOluwa, Aiyedire, Ayedaade and Irewole .It has a population of about 191,348 people (NPC, 2006). The city has coordinates of $7^{\circ} 37^{\prime} 45.1524^{\prime \prime} \mathrm{N}$ and $4^{\circ} 11^{\prime}$ 13.9848" E. The major occupation of the people in the study area are farming and trading. The farming system include growing of crops such as vegetable, cassava, maize and livestock like sheep, poultry, rabbit, snail, goat and cattle.

\section{Sampling technique and sample size}

Population of the study consists of households who engaged in mini-livestock production species such as rabbit, grass cutter, guinea pig, snails, honey bee and, quail. Multi-stage sampling procedure was used for this study. The first stage involved random selection of $50 \%$ of communities in Iwo Local Government Area out of 12 communities to give 6 communities. Snowball technique was then used at the second stage to generate the list of households who engage in mini-livestock production in the selected communities. The third stage involved random selection of at least twenty-five households who are involved in mini-livestock production in each community to give rise to 150 respondents.

\section{Data collection}

Data were collected using well structure interview schedule to elicit information from the respondents on their socioeconomic characteristics (such as age, sex, religion, marital status, income, educational level) and mini-livestock production enterprises such as years of experience, species of mini-livestock, flock inflow, flock outflow, flock size, income realized from sales, purpose of production).

\section{Data analysis}

Household food security status was estimated using the food security index and classifying households into food secured and food insecured. To identify factors influencing the food security status of the households, a two-stage analysis was done. In the first stage, the adoption of the food security index was used to classify the households according to their food security status using the food security line as determined by their expenditure on food (Omonona and Agoi, 2007). In the second stage, a logit regression model was specified. In the model, food security status of the households was a function of a set of independent variables. Any household whose per capita monthly food expenditure fall above or is equal to the food security line is food secured. On the other hand, a food insecure household is that whose per capita food expenditure falls below the food security line. The index is given by:

$F=\frac{\text { Per capital food expenditure for ith household }}{2 / 3 \text { Mean per capita food expenditure of all household }}$

Where: $F=$ Food Security Index, F $>1=$ Food Secured Household and $\mathrm{F} \leq 1=$ Food Insecured Household (Ogunniyi et al., 2015).

Data were also subjected to both descriptive statistics such as (mean, frequency and percentage) and inferential statistics such as chi-square and regression analysis.

\section{RESULTS}

\section{Socio-economic characteristics of the respondents}

Socio-economic characteristics of respondents are presented in Table 1. Result shows that majority of the respondents were male $(72.8 \%)$, while $27.2 \%$ of them were female, most of the respondents were within the age range of 20 to 24 years. The mean age (23.1 years) of the respondents is a confirmation of the economic activeness of the respondents based on their ages. Most 
Table 1. Socio-economic characteristics of the respondents.

\begin{tabular}{|c|c|c|c|}
\hline Variable & Frequency & Percentage & Mean \\
\hline \multicolumn{4}{|l|}{ Sex } \\
\hline Male & 110 & 72.8 & \\
\hline Female & 41 & 27.2 & \\
\hline \multicolumn{4}{|l|}{ Age (Years) } \\
\hline $20-24$ & 39 & 25.8 & \multirow{5}{*}{23.1} \\
\hline $25-29$ & 54 & 35.8 & \\
\hline $30-34$ & 39 & 25.8 & \\
\hline $35-39$ & 10 & 6.6 & \\
\hline$>39$ & 9 & 6.0 & \\
\hline \multicolumn{4}{|l|}{ Marital Status } \\
\hline Single & 53 & 35.1 & \\
\hline Married & 83 & 55.0 & \\
\hline Divorced & 8 & 5.3 & \\
\hline \multicolumn{4}{|l|}{ Educational Level } \\
\hline No Formal Education & 14 & 9.3 & \\
\hline Primary Education & 30 & 19.9 & \\
\hline Secondary Education & 83 & 55.0 & \\
\hline Tertiary Education & 24 & 15.9 & \\
\hline \multicolumn{4}{|l|}{ Religion } \\
\hline Islam & 57 & 37.7 & \\
\hline Christianity & 79 & 52.3 & \\
\hline Traditional & 15 & 10.0 & \\
\hline \multicolumn{4}{|l|}{ Household Size } \\
\hline $2-5$ & 69 & 45.7 & \multirow{4}{*}{2.7} \\
\hline $6-9$ & 64 & 42.4 & \\
\hline $10-13$ & 13 & 8.6 & \\
\hline$>13$ & 5 & 3.3 & \\
\hline \multicolumn{4}{|c|}{ Years of experience in mini-livestock production } \\
\hline $2-5$ & 51 & 33.8 & \multirow{4}{*}{2.0} \\
\hline $5-8$ & 73 & 48.3 & \\
\hline $9-12$ & 18 & 11.9 & \\
\hline$>12$ & 9 & 6.0 & \\
\hline \multicolumn{4}{|l|}{ Primary Occupation } \\
\hline Trading & 20 & 13.2 & \\
\hline Civil Servant & 31 & 20.5 & \\
\hline Farming & 53 & 35.1 & \\
\hline Artisan & 47 & 31.2 & \\
\hline
\end{tabular}


Table 1. Contd.

\begin{tabular}{lccc}
\hline Income $(\mathrm{A})$ & & & \\
& 33 & 21.9 & \\
$<5000$ & 55 & 36.4 & 18331.0 \\
$5001-10,000$ & 42 & 27.8 & \\
$10,001-15,000$ & 12 & 7.9 & \\
$15,001-20,000$ & 9 & 6.0 & \\
$>20,000$ & & & \\
& & & \\
Amount Spent On Food (Weekly) (N) & & 35.1 & \\
$>500$ & 1 & 0.7 & \\
$500-1000$ & 8 & 5.3 & \\
$1001-1500$ & 14 & 9.3 & \\
$1501-2000$ & 14 & 9.3 & \\
$2001-2500$ & 12 & 7.9 & \\
$2501-3000$ & 49 & 32.5 & \\
$<3000$ & &
\end{tabular}

$(55.0 \%)$ of the respondents were married, had secondary education (55\%), had household size of between 2 to 5 members $(45.7 \%)$. The mean of household size was 3 . The study further revealed that $52.3 \%$ of the respondents were Christian. Most of the respondents had 5 to 8 years of experience in minilivestock production. They were farmers and earned more than $\mathrm{N} 5,000$ as income and spent within the range of less than $\mathrm{N} 500$ on food.

\section{Mini-livestock production characteristics of respondent}

Result showed that most of the respondents raised minilivestock purposely for income generation (72.2 \%) and sourced their flocks from wild $(39.1 \%)$. Majority of the respondents earned between N5001 to N10, 000 from sales of their stocks in the study area. Most of the respondents were raising snail $(25.2 \%)$, this was closely followed by those raising grass cutter $(24.5 \%)$, rabbit $(23.2 \%)$ while few were raising honey bee $(11.3 \%)$ guinea pig $(9.9 \%)$ and quail $(6 \%)$ the least (Table 2$)$.

\section{Level of food security among the households}

Households were classified into food secured and food insecured households based on their per capita food expenditure. Result shows that more households were food secured than those that were food insecured (Table 3).

\section{Distribution of food security status of respondents based on their mini-livestock rearing combination}

Result showed that more than half of the respondents $(58.3 \%)$ who reared one species of mini-livestock were food secured while $41.7 \%$ were food insecured (Table 4). Also, more than half of the respondents $(55.7 \%)$ who reared two or more species of mini-livestock were food secured. Those who rear and combine three species of mini-livestock were $100 \%$ food secured. There was a positive and significant relationship $(r=0.687 ; P<0.05)$ between food security status of the respondents and their mini-livestock species production combinations. The result also showed that most of the respondents (87.4\%) raised one mini-livestock followed by those who raised two combination of mini-livestock production (11.9\%) and few of the respondents raised a combination of three mini-livestock (0.7\%).

\section{Determinants of food security}

The determinants of food security among the respondents are presented in Table 5. Primary occupation and income from sales of mini-livestock were found to be significant determinants of food security status among respondents in the study area. Primary occupation had a positive coefficient and significant at 5\% (Table 5). The coefficient of income realized from sales of mini-livestock $(0.107)$ was positive and significant at $5 \%$, implying that as the income realized from sales of mini-livestock by the respondents increase, more money is earned resulting 
Table 2. Mini-livestock production characteristics within the respondents.

\begin{tabular}{|c|c|c|c|}
\hline Characteristics & Frequency & Parentage & Mean \\
\hline \multicolumn{4}{|c|}{ Purpose of Production } \\
\hline Income Generation & 109 & 72.2 & \\
\hline Consumption & 35 & 23.2 & \\
\hline Hobby & 7 & 4.6 & \\
\hline \multicolumn{4}{|l|}{ Sources Flock Inflow } \\
\hline Market & 35 & 23.2 & \\
\hline Wild & 59 & 39.1 & \\
\hline Neighborhood & 8 & 5.3 & \\
\hline Gift & 23 & 15.2 & \\
\hline Contract & 14 & 9.3 & \\
\hline Inheritance & 8 & .3 & \\
\hline Research Institutes & 4 & 2.6 & \\
\hline \multicolumn{4}{|c|}{ Income Generated From Sales of Mini-Livestock ( $\mathrm{N}$ ) } \\
\hline$<5000$ & 22 & 14.6 & \\
\hline $5001-10,000$ & 63 & 41.7 & \\
\hline $10,001-15,000$ & 40 & 26.5 & $25,500.00$ \\
\hline $15,001-20,000$ & 13 & 8.6 & \\
\hline$>20,000$ & 13 & 8.6 & \\
\hline \multicolumn{4}{|c|}{ Species of Mini-Livestock Raised by Respondents } \\
\hline Rabbit & 35 & 23.2 & \\
\hline Snail & 38 & 25.2 & \\
\hline Quail & 9 & 6.0 & \\
\hline Guinea Pig & 15 & 9.9 & \\
\hline Grasscutter & 37 & 24.5 & \\
\hline Honey Bee & 17 & 11.3 & \\
\hline
\end{tabular}

Table 3. Distribution of respondents using food security Indices.

\begin{tabular}{lcc}
\hline Farmers Group & Frequency & Percentage \\
\hline Food Secured & 88 & 58.3 \\
Food Insecure & 63 & 41.7 \\
\hline
\end{tabular}

to increased food security status of the respondents.

\section{DISCUSSION}

The result of socioeconomic characteristics of respondent implies that more males were involved in mini-livestock production than female counterparts. The age of most of the respondents implies that majority of the respondents were still in their economically active ages. The mean age (23.1 years) of the respondents is a confirmation of the economic activeness of the respondents based on their age. Age is an important factor in agricultural production because it has a direct relationship with productivity. The result of this study agrees with report of Akinbile (1994) that agricultural production is still for the middle ages and old people. This also implies that age of individuals affect their levels of involvement in minilivestock production. Marital status of most of the respondents was as expected with the result of age range of the respondents in the study area. Educational level of majority of the respondents is an indication that information dissemination as well as adoption of innovations will be more enhanced since most of the 
Table 4. Distribution of food security status of respondents based on their Mini-livestock rearing combinations S.

\begin{tabular}{lcccccc}
\hline \multirow{2}{*}{ Food Security Status } & \multicolumn{2}{c}{ One Mini-Livestock } & \multicolumn{2}{c}{ Two Mini-Livestock } & \multicolumn{2}{c}{ Three MiniLivestock } \\
\cline { 2 - 6 } & Frequency & Percentage & Frequency & Percentage & Frequency & Percentage \\
\hline Food Secured & 77 & 58.3 & 10 & 55.6 & 1 & 100.0 \\
Food Insecured & 55 & 41.7 & 8 & 44.4 & 0 & 0.0 \\
Total & 132 & & 18 & & 1 & \\
\hline
\end{tabular}

Table 5. Determinants of Food Security among the Respondents.

\begin{tabular}{lcc}
\hline Explanatory variables & Coefficient & t-value \\
\hline Constant & -0.017 & 0.238 \\
Sex & -0.072 & -0.874 \\
Marital Status & -0.052 & 0.285 \\
Educational Level & -0.045 & 0.616 \\
Religion & -0.014 & -0.280 \\
Household Size & -0.015 & -0.244 \\
Years of Experience & -0.084 & -1.448 \\
Primary Occupation & -0.065 & $1.046^{*}$ \\
Income & -0.098 & 3.005 \\
Purpose of Mini-Livestock Production & -0.020 & -4.555 \\
Flock Inflow & -0.043 & 0.608 \\
Income from sales of Mini-Livestock & -0.014 & $-0.571^{*}$ \\
Species of Mini-Livestock Reared & -0.107 & -2.681 \\
Log likelihood function = 38.116 & & \\
Chi-square = 20.342 & & \\
Degrees of freedom $=12$ & & \\
\hline
\end{tabular}

*Significant at 5\%.

respondents can write and read. This finding agreed with report of Asanwana (2001) that educated farmers can easily understand and adopt new innovations and improved practices. Household size is an important variable that determines the total household food requirement and thus affect per capita food consumption and household food security. This result was similar to that of Odebode and Munsong (2001) and Bammeke (2003) who reported household size of between 2 to 6 people as the modal family size among households. Analysis of the profile of the respondents as regards their belief or religious group indicated that religion does not have any taboo on mini-livestock production among the respondents. This study presents various primary occupations engaged in by the respondents. The result shown that the main source of livelihood for the majority of respondents was farming which also implies that respondents are not only involved in one income generating activity as means of increasing it but to improve livelihood and their food security status. As regards income generated by respondents, the remarkable difference in income realized is due to differences in the occupation of the respondents which also translate to amount spent on food.
The result of mini-livestock production enterprise of the respondents shown that it is a lucrative enterprise considering the facts the species mostly produced (snail) was sourced from wild and not bought in most cases and it commands high demand and good price. The highest proportion of farmers rearing snail could be attributed to the fact that snail can be easily sourced and picked from wild with low or no financial input. Also snail meat is well accepted in many parts of Nigeria (Odunnaiya, 1991). Similar result was reported by Ogunniyi et al. (2015) as regards the specie of mini-livestock mostly produced by respondents.

Households were classified into two groups namely food secured and food insecured base on their per capita food expenditure. The food insecurity line was defined as two third of the mean per capita food expenditure of the total household. It was obtained that mean per capital household food expenditure for this study was N2405.30 while the 2/3 mean per capital household expenditure was N1603.53. Thus, household whose food security as indicated by the index is greater than or equal to 1 is said to be food secured while household whose food security index is less than 1 is said to be food insecured. The result thus shows that more households are food secured. 
Table 6. Relationship between food security status of the respondents and their mini-livestock rearing combination.

\begin{tabular}{lccl}
\hline Variables & r & p-value & Significant Level \\
\hline $\begin{array}{l}\text { Food Security Status and Mini-Livestock } \\
\text { production Combination }\end{array}$ & 0.687 & 0.001 & Significant \\
\hline
\end{tabular}

There was positive, strong and significant relationship between food security status of the respondents and their minilivestock species production combinations (Table 6). This implies that the more the mini-livestock respondents reared (in combination), the more food secured they are. By implication, rearing more than one mini-livestock had better returns on production, generates more income and hence the households become more food secured. The result of this study agreed with result of Ogunniyi et al. (2015) who reported that farmers who rear one and two mini-livestock species had better returns on their production, generate more streams of income and these make them to be food secured.

Primary occupation and income from sales of minilivestock were found to be significant determinants of food security status among the respondents in the study area. Primary occupation $(0.098)$ had a positive coefficient and significant at $5 \%$. This implies that better occupation with high income would increase the food security status of the respondents. The coefficient of income realized from sales of minilivestock (0.107) was positive and significant at $5 \%$, implying that as the income realized from sales of mini-livestock by the respondents increase, more money is earned resulting to increased food security status of the respondents.

\section{Conclusion}

Based on the result of this study, it was concluded that majority of households in the study area were food secured. There was significant and strong correlation between raising of more than one species of minilivestock and food security of the households. Also, primary occupation and income realized from sales of mini-livestock production were found to be significant determinants of food security among households. There is need to create awareness and sensitize households on the importance of mini livestock production.

\section{REFERENCES}

Akinbile, L. A. (1994). Analysis of the attitudes of maize farmers to indigenous and scientific knowledge in Odeda Local Government, Ogun State. M.Sc. Degree Project, Department of Agricultural Extension and Rural Development, University of Ibadan.

Assan, N. (2014). Relevance and feasibility of mini livestock farming in enhancing food security in Southern Africa. Agricultural Advances, 3(10), 261-267

Asanwana, V. A. (2001). Coping strategies for Enhanced Rural Household Food Security among Female Farmers in Akwalbom state, Nigeria. Ph.D Thesis submitted to Department of Agricultural Extension and Rural Development University of Ibadan, Ibadan.

Babatunde, R. O., Omotesho, O. A., and Sholotan, O. S. (2007). Socio economic characteristics and food security status of farming households in Kwara State, North Central Nigeria. Pakistan Journal of Nutrition. 1, 49-58.

Bammeke, T. O. A. (2003). Accessibility and utilization of agricultural information in the economic empowerment of women farmers in South-western Nigeria. Ph.D. Thesis, Department of agricultural Extension and Rural Development, University of Ibadan, Pp. 97-120.

FAO (2004). Technology review: Newcastle disease with special emphasis on its effect on village chickens. Animal Production and Health, Paper No.161.

FAO (2010). The state of food insecurity in the world: addressing food insecurity in protracted crises. Food and Agriculture Organization of the United Nations, Rome.

Hardouin, J., Thys, E., Joiris, V., \& Fielding, D. (2003). Minilivestock breeding with indigenous species in the tropics. Livestock Research for Rural Development, (15)4.

Morris, P. M., Neuhauser, L., \& Campbell, C. (1992). Food security in rural America: a study of the availability and costs of food. Journal of Nutrition Education, 24(1), 52S-58S.

National Population Commission, Nigeria (2006). Census Report.

Odebode, S. O., \& Mungong, C. H. (2001). Poverty Alleviation Strategies of Rural households in Mezan Division, North West Province, Cameroon, Moor Journal of Agricultural Research, 2(2), 179-185.

Odunnaiya, O. (1991). Studies on the Growth Rate of a marginataFed Pawpaw Leaf, Waterleafand maize chaff. Unpublished B. Agric thesis, Ogun State University, AgoIwoye, Nigeria.

Ogunniyi, L. T., Oluwafemi, Z. O., \& Adepoju, A. A. (2015).MiniLivestock Farming as a Strategy for Food Security in Oyo State of Nigeria. Journal of Agriculture and Sustainability, 7(2), 171-186

Okunmadewa, F., Olomola, A., \& Adubi, B. (1990). Trade liberalization and food security: situation analysis in Nigeria. Research report for development policy centre, Ibadan, Nigeria.

Omonona, B. T., \& Agoi, G. A. (2007). An analysis of food security situation among Nigeria urban households: evidence from Lagos State, Nigeria. Journal Of Central European Agriculture. 8(3), 397-406.

Sanusi, R. A. Badejo, C. A., \& Yesufu, B. O. (2006). Measuring household food insecurity in selected local government in Lagos and Ibadan. Pakistan journal of nutrition, 5(1), 62-67. 